\title{
Original paper \\ The role of silver in the crystal structure of pyrargyrite: single crystal X-ray diffraction study
}

\author{
František LAUFEK ${ }^{1 *}$, Jiří SEJKORA², Michal DUŠEK ${ }^{3}$ \\ ${ }^{1}$ Czech Geological Survey, Geologická 6, 15200 Prague 5, Czech Republic; frantisek.laufek@geology.cz \\ ${ }^{2}$ Department of Mineralogy and Petrology, National Museum, Václavské nám. 68, 11579 Prague 1, Czech Republic \\ ${ }^{3}$ Institute of Physics AS CR, v.v.i., Na Slovance 2, 18221 Prague 8, Czech Republic \\ * Corresponding author
}

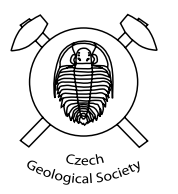

The crystal structure of pyrargyrite, $\mathrm{Ag}_{3} \mathrm{SbS}_{3}$, from Př́ibram-Háje (Czech Republic) was refined from single-crystal $\mathrm{X}$-ray diffraction data in the space group $R 3 c$ to an $R$ factor of 0.0112 . Unit-cell parameters are $a=11.0464(3) \AA$, $c=8.7211(2) \AA, V=921.60(4) \AA^{3}, Z=6$. In order to mimic the spread of electron density of silver, the non-harmonic Gram-Charlier development of the silver atomic displacement parameters was applied. A reasonable triangular shape of the electron density maximum centred in Ag position was obtained. The analysis of potential barriers between Ag sites reveals that silver transfer is equally probable via additional $\mathrm{P}$ site not only within the $\mathrm{Ag}-\mathrm{S}-\mathrm{Ag}$ spirals and the $\mathrm{Ag}-\mathrm{Ag}$ chains, but also between these spirals and chains.

Keywords: pyrargyrite, crystal structure, non-harmonic refinement, Ag diffusion, atomic displacement parameters Received: 26 April 2010; accepted: 7 July 2010; handling editor: R. Skála

\section{Introduction}

Pyrargyrite, $\mathrm{Ag}_{3} \mathrm{SbS}_{3}$, is Ag-rich sulphosalt rather common in epithermal polymetallic base-metal sulphide deposits of the fissure-vein type (Harlov and Sack 1995). Together with its low temperature modification - pyrostilpnite - pyrargyrite belongs to the proustite-xanthoconite group (Strunz and Nickel 2002). Pyrargyrite represents $\mathrm{Sb}$ end-member of solid solution with isostructural proustite, $\mathrm{Ag}_{3} \mathrm{AsS}_{3}$. This solid solution is believed to be continuous down to $90^{\circ} \mathrm{C}$ (Ghosal and Sack 1995). From the chemical point of view, these two mineral phases can be considered as ones of the simplest Ag-bearing sulphosalts.

As was mentioned by Bindi and Evain (2007), disorder is commonly observed during the structure solution and refinement of $\mathrm{Ag}^{+}$and $\mathrm{Cu}^{+}$bearing sulphosalts. Gaudin et al (2001) reported that $\mathrm{Ag}^{+}$and $\mathrm{Cu}^{+}$ions with electron configuration $d^{10}$ easily adopt various complex asymmetric coordinations. The main factors influencing the coordination of $\mathrm{Ag}^{+}$and $\mathrm{Cu}^{+}$ions in chalcogenides are the metal $s / d$ orbital mixing and polarization factors (Gaudin et al. 2001). Then, $\mathrm{Ag}^{+}$and $\mathrm{Cu}^{+}$ions can occur in different, but overlapping sites and the crystal structure appears as disordered. A classical approach to address disordered materials is the application of a split atom model. Bindi and Evain (2007) demonstrated that the non-harmonic approach based on Gram-Charlier development of the atomic displacement factors (Kuhs 1992) represents an alternative and more effective way to determine and describe the structure of such materials. The efficiency of the non-harmonic approach has been recently proven by successful application to solution and refinement of various Ag-bearing sulphides and sulphosalts, e.g. samsonite, $\mathrm{Ag}_{4} \mathrm{MnSb}_{2} \mathrm{~S}_{6}$ (Bindi and Evain 2007), stephanite, $\mathrm{Ag}_{5} \mathrm{SbS}_{4}$ (Leitl et al. 2009), pearceite-polybasite group minerals, $\left[(\mathrm{Ag}, \mathrm{Cu})_{16} \mathrm{MS}_{11}\right.$ where $\left.\mathrm{M}=\mathrm{Sb}, \mathrm{As}\right]$ (Bindi et al. 2006, 2007a, b), and many others. This approach has also been applied to crystal structure studies of Ag-based ionic conductors from the argyrodite group, $\mathrm{Ag}_{8} \mathrm{MX}_{6}$ where $\mathrm{M}=\mathrm{Ge}, \mathrm{Sn}, \mathrm{Si}, \mathrm{P} ; \mathrm{X}=\mathrm{S}$, Se, Te (e.g. Boucher et al. 1993; Gaudin et al. 2000).

The crystal structure of pyrargyrite was determined for the first time by Harker (1936) using the three-dimensional Patterson method. Later, Engel and Nowacki (1966) refined the pyrargyrite structure to $\mathrm{R}=6.9 \%$ with all atoms described as anisotropic, however exhibiting rather high values of displacement parameters for the $\mathrm{Ag}$ atoms in comparison to $\mathrm{Sb}$ and $\mathrm{S}$ atoms $\left(B_{\text {iso }}\right.$ values of $4.67,1.14$ and $1.16 \AA^{2}$ for $\mathrm{Ag}, \mathrm{Sb}$ and $\mathrm{S}$ atoms, respectively).

Gagor et al. (2009) recently refined the crystal structure of synthetic proustite using non-harmonic approach. Pyrargyrite and proustite are not only isostructural, they also display similar physical properties and crystal habit. Both mineral phases were investigated using impedance spectroscopy as possible ionic conductors by Schönau and Redfern (2002). In such Ag-bearing ionic conductors, $\mathrm{Ag}^{+}$ cations can move easily above a transition temperature, giving a liquid-like structure in an open framework. The migration of silver is facilitated when there exists a low activation energy for atomic jumps (Bindi et al. 2006). The distribution of silver ions in the crystal structure may 
play a major role in changes of physical properties of the studied minerals with temperature (Schönau and Redfern 2002). Among Ag-bearing sulphosalts, the ionic conductivity was also described for the pearceite-polybasite group minerals (Bindi et al. 2006), stephanite (Leitl et al. 2009) and pyrargyrite (Gagor et al. 2009).

Therefore, the aim of this work was to perform full anisotropic refinement of the crystal structure of pyrargyrite and to evaluate the effect of the application of Gram-Charlier development on the atomic displacement parameters. In order to provide information about the possible diffusion pathways of $\mathrm{Ag}$ in the pyrargyrite structure, the joint probability density function and oneparticle potential of $\mathrm{Ag}$ atoms were also calculated.

\section{Occurrence and chemical composition}

The refinement of the crystal structure of pyrargyrite presented in this paper was carried out on sample of pyrargyrite from the $\mathrm{H} 61 \mathrm{Z}$ vein (shaft No. 21) of the Háje ore deposit, the Př́bram uranium-base metals ore district, Czech Republic (Sejkora et al. 2007). Pyrargyrite forms massive aggregates in calcite and well-developed crystals up to $1 \mathrm{~cm}$ in size associated with pyrostilpnite crystals, pyrite, löllingite, silver, acanthite as well as supergene argentojarosite and gypsum (Sejkora et al. 2007). The colour of pyrargyrite crystals is dark reddish brown to black with abundant red internal reflections; it has metallic lustre and reddish streak.

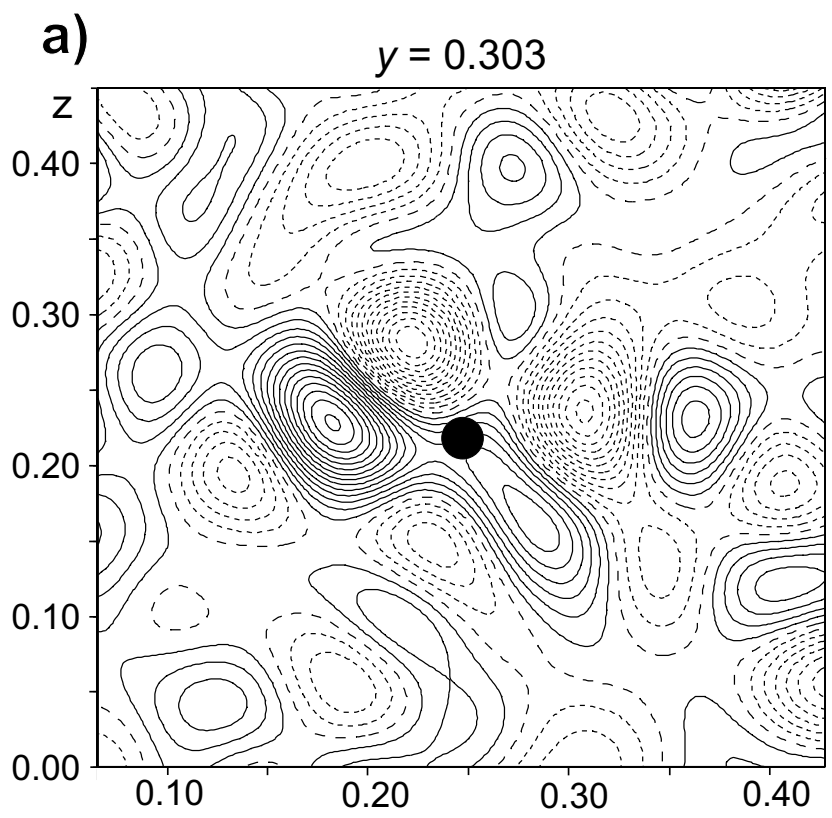

Quantitative chemical analyses were performed with a Cameca SX100 electron microprobe (State Geological Survey, Bratislava, Slovakia) in the wavelength-dispersion mode with an accelerating voltage of $20 \mathrm{kV}$, a sample current of $20 \mathrm{nA}$, and a beam diameter of 8-40 $\mu \mathrm{m}$. The following standards and X-ray lines were used: Ag metal $\left(\mathrm{Ag} L_{\alpha}\right), \mathrm{PbS}\left(\mathrm{Pb} M_{\alpha}\right), \mathrm{CuFeS}_{2}\left(\mathrm{Cu} K_{\alpha}, \mathrm{Fe} K_{\alpha}, \mathrm{S} K_{\alpha}\right)$, $\mathrm{Cd}$ metal $\left(\mathrm{Cd} L_{\alpha}\right), \mathrm{NaCl}\left(\mathrm{Cl}_{\alpha}\right), \mathrm{Sb}_{2} \mathrm{~S}_{3}\left(\mathrm{Sb}_{\beta}\right)$, Bi metal $\left(\mathrm{Bi} L_{\alpha}\right)$, FeAsS $\left(\operatorname{As} K_{\beta}\right)$ and $\mathrm{ZnS}\left(\mathrm{Zn} K_{\alpha}\right)$. Raw intensities were converted to the concentrations using automatic $P A P$ (Pouchou and Pichoir 1985) matrix correction software package. Contents of $\mathrm{Cu}, \mathrm{Fe}, \mathrm{Cd}, \mathrm{Bi}, \mathrm{As}$ and $\mathrm{Zn}$ were quantitatively sought for but were below the respective detection limits (c. 0.01-0.03 wt. \%).

Chemical composition of the studied pyrargyrite sample, Ag 60.30 (60.24-60.35), Pb 0.07 (0.04-0.10), $\mathrm{Sb} 22.30$ (22.20-22.40), S 17.52 (17.51-17.54), Cl 0.07, total 100.26 wt. \% (Sejkora et al. 2007) yielded the empirical formula $\mathrm{Ag}_{3.04} \mathrm{Sb}_{0.99}\left(\mathrm{~S}_{2.96} \mathrm{Cl}_{0.01}\right)_{\Sigma 2.97}$ calculated on the basis of $7 a p f u$. Examined pyrargyrite from Háje near Př́ibram is As-free member of pyrargyrite-proustite solid solution, because As contents were under detection limit of the used method.

\section{X-ray crystallography and structure determination}

Data for crystal structure refinement were collected using single-crystal CCD diffractometer Gemini of

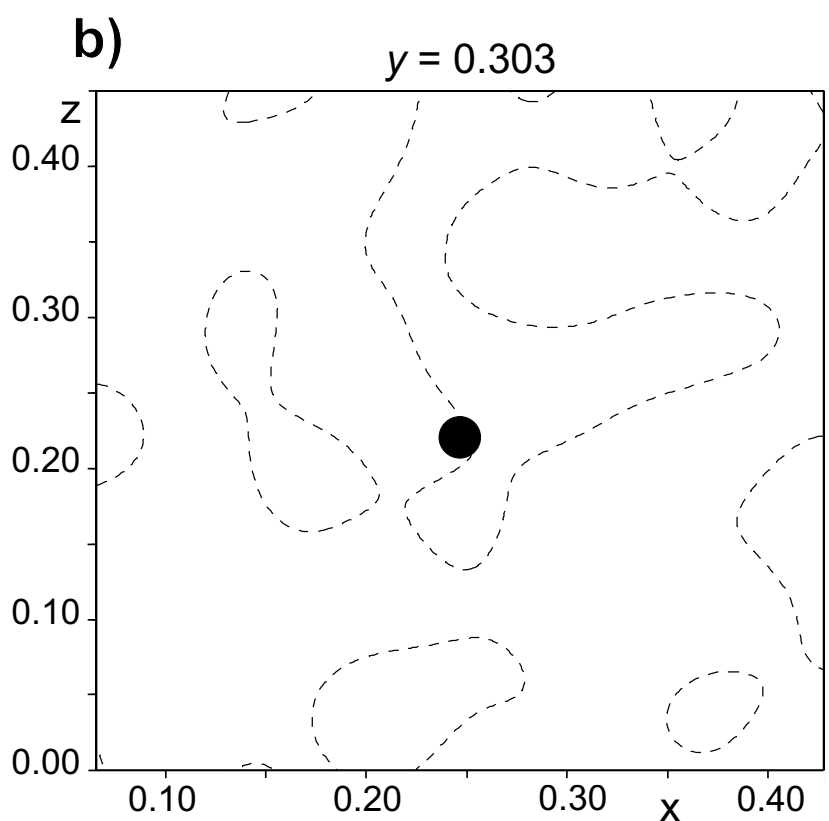

Fig. 1 Difference Fourier maps for pyrargyrite centred at Ag position. Contour lines are in intervals $0.1 \mathrm{e} / \AA^{3}$ for positive values (continuous lines) and negative values (dashed lines). a - Classic anisotropic refinement; $\mathbf{b}$ - Non-harmonic refinement of Ag atoms. 
Oxford Diffraction. Integration of the CCD images and data reduction was performed by the program Crysalis RED (Oxford Diffraction 2008). The same program was used for indexing of the crystal shape and corresponding absorption correction. The crystal shape was also optimised by program X-Shape (Herrendorf 1993). The crystal structure of pyrargyrite was solved by applying the Superflip program (Palatinus and Chapuis 2007). Subsequent structure refinements were carried out with the JANA2006 program suite (Petříček et al. 2006). The refinements were performed on $F^{2}$, with all measured reflections included up to $0.8 \AA$.

The refinement of pyrargyrite converged quickly to an acceptable value of $R=0.0384$ for 430 reflections $[\mathrm{I}>3 \sigma(\mathrm{I})]$ and 22 parameters. However, the residuals up to 1.99 and $-1.51 \mathrm{e}^{-} / \AA^{3}$ were found in the Fourier difference maps in the vicinity of the Ag atom (Fig. 1a). They did not occur at random thus representing refinement model inadequacy. Similar observation was described during the refinement of samsonite, $\mathrm{Ag}_{4} \mathrm{MnSb}_{2} \mathrm{~S}_{6}$, by Bindi and Evain (2007). The introduction of the thirdorder non-harmonic Gram-Charlier tensors for the Debye-Waller description of $\mathrm{Ag}$ atoms led to a significant decrease in the $R$ factor to the value of 0.0112 for 32 parameters and to a considerable drop of residuals in the difference Fourier maps $\left(0.12\right.$ and $-0.11 \mathrm{e}^{-/} \AA^{3}$, Fig. $\left.1 \mathrm{~b}\right)$. Experimental details and crystal data are listed in Tab. 1, atomic positions and anisotropic displacement parameters in Tabs 2 and 3, respectively. High-order displacement parameters for the Ag atom are given in Tab. 4.

\section{Results and discussion}

\subsection{Description of the pyrargyrite structure}

Our study has confirmed the atomic arrangement of this mineral reported by Engel and Nowacki (1966). The crystal structure of pyrargyrite contains covalently bonded $\mathrm{SbS}_{3}$ pyramids, which are stacked in columns parallel with [001] direction. These $\mathrm{SbS}_{3}$ pyramids preserve the orientation of their $\mathrm{Sb}$ vertices along the polar three-fold $\mathbf{c}$ axis (Fig. 2). The sum of $\mathrm{S}-\mathrm{Sb}-\mathrm{S}$ bonding angles of $292.4^{\circ}$ in the $\mathrm{SbS}_{3}$ pyramids is consistent with that value obtained for pyrostilpnite $\left(294.8^{\circ}\right.$, Kutoglu 1968) and slightly higher than that value observed in stephanite, $\mathrm{Ag}_{5} \mathrm{SbS}_{4}\left(285.7^{\circ}\right.$, Leitl et al. 2009). The Sb-S distance of $2.444 \AA$ is comparable with the mean $\mathrm{Sb}-\mathrm{S}$ distances of $2.450 \AA$ and $2.438 \AA$ observed in pyrostilpnite (Kutoglu 1968) and stephanite structure (Leitl et al. 2009), respectively.
Tab. 1 Crystallographic data and experimental details for pyrargyrite

\begin{tabular}{|c|c|}
\hline Chemical formula & $\mathrm{Ag}_{3} \mathrm{SbS}_{3}$ \\
\hline Temperature (K) & 295 \\
\hline Space group & $R 3 c($ No. 161$)$ \\
\hline \multirow[t]{2}{*}{ Unit cell parameters $(\AA)$} & $a=11.0464(3)$ \\
\hline & $c=8.7211(2)$ \\
\hline Volume $\left(\AA^{3}\right)$ & $921.60(4)$ \\
\hline Z & 6 \\
\hline Calculated density $\left(\mathrm{g} \mathrm{cm}^{-3}\right)$ & 5.85 \\
\hline Crystal colour & black \\
\hline Crystal shape & irregular \\
\hline Absorption coefficient $\left(\mathrm{mm}^{-1}\right)$ & 14.549 \\
\hline Absorption correction & analytical \\
\hline Crystal size (mm) & $0.163 \times 0.105 \times 0.073$ \\
\hline Radiation & $\operatorname{Mo} K_{\alpha}(\lambda=0.71073 \AA)$ \\
\hline Range for data collection $\left({ }^{\circ}\right)$ & $3.68-26.42$ \\
\hline \multirow[t]{3}{*}{$h k l$ ranges } & $-13 \leq h \leq 13$ \\
\hline & $-13 \leq \mathrm{k} \leq 13$ \\
\hline & $-10 \leq l \leq 10$ \\
\hline Number of reflections & 3601 \\
\hline Independent reflections $[\mathrm{I}>3 \sigma(\mathrm{I})]$ & 430 \\
\hline$R_{\text {int }}$ & 0.0188 (all) \\
\hline Refinement & Full-matrix least squares on $F^{2}$ \\
\hline Weighting scheme & $w=1 /\left[\sigma^{2}(I)+(0.0016 \times I)^{2}\right]$ \\
\hline Data/restrains/parameters & $430 / 0 / 32$ \\
\hline$R_{\mathrm{obs}} / R_{\mathrm{all}}$ & $0.0112 / 0.0112$ \\
\hline$w R_{\mathrm{obs}} / w R_{\mathrm{all}}$ & $0.0418 / 0.0418$ \\
\hline Goodness of Fit (obs.) & 1.05 \\
\hline Difference Fourier $\left(\mathrm{e}^{-} / \mathrm{A}^{3}\right)$ & $0.12 /-0.11$ \\
\hline
\end{tabular}

Tab. 2 Atomic coordinates and equivalent isotropic displacement parameters $U_{\text {eq }}\left(\AA^{2}\right)$ for pyrargyrite

\begin{tabular}{lccccc}
\hline Atom & Wyckoff & $x$ & $y$ & $z$ & $U_{\text {eq }}$ \\
\hline $\mathrm{Sb}$ & $6 a$ & 0 & 0 & 0 & $0.0197(1)$ \\
$\mathrm{Ag}$ & $18 b$ & $0.2469(3)$ & $0.3031(2)$ & $0.2184(4)$ & $0.0727(3)$ \\
$\mathrm{S}$ & $18 b$ & $0.2215(4)$ & $0.1007(4)$ & $0.3609(5)$ & $0.0233(4)$ \\
\hline
\end{tabular}

Tab. 3. Anisotropic displacement parameters $\left(\AA^{2}\right)$ for pyrargyrite

\begin{tabular}{lcccccc}
\hline Atom & $U_{11}$ & $U_{22}$ & $U_{33}$ & $U_{12}$ & $U_{13}$ & $U_{23}$ \\
\hline $\mathrm{Sb}$ & $0.0207(2)$ & $0.0207(2)$ & $0.0178(2)$ & $0.0103(1)$ & 0 & 0 \\
$\mathrm{Ag}$ & $0.0986(4)$ & $0.0520(3)$ & $0.0677(3)$ & $0.0378(3)$ & $0.0020(3)$ & $0.0310(3)$ \\
$\mathrm{S}$ & $0.0188(5)$ & $0.0213(4)$ & $0.0281(5)$ & $0.0089(3)$ & $0.0016(4)$ & $0.0010(3)$ \\
\hline
\end{tabular}

Tab. 4 The high order non-harmonic displacement parameters $C_{\mathrm{ijk}}$ for the $\mathrm{Ag}$ atom in pyrargyrite

\begin{tabular}{llllll}
\hline$C_{111}$ & $C_{112}$ & $C_{113}$ & $C_{122}$ & $C_{123}$ & $C_{133}$ \\
$-0.0129(5)$ & $-0.0005(3)$ & $0.0058(3)$ & $0.0041(2)$ & $0.0069(2)$ & $0.0097(2)$ \\
$C_{222}$ & $C_{223}$ & $C_{233}$ & $C_{333}$ & & \\
$0.0060(3)$ & $0.0068(2)$ & $0.0062(2)$ & $0.0053(7)$ & & \\
\hline
\end{tabular}




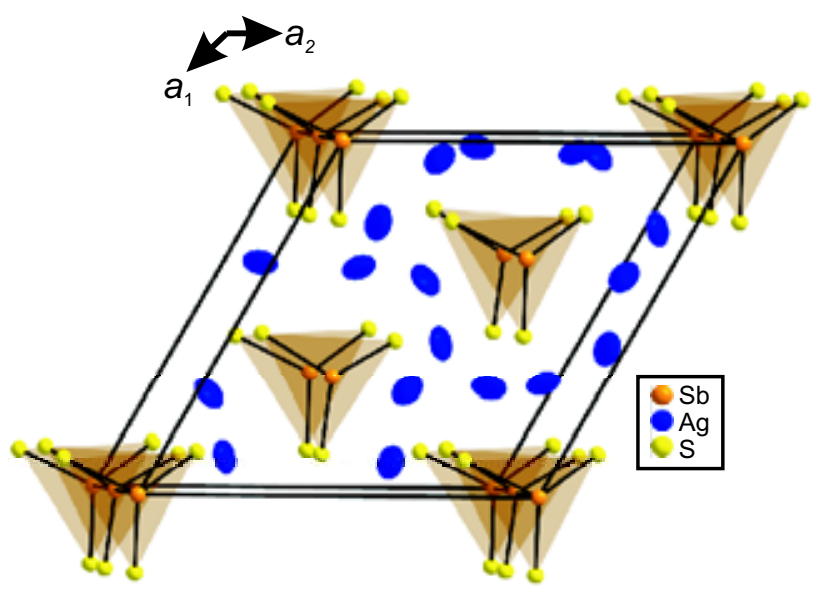

Fig. 2 The crystal structure of pyrargyrite viewed along the $\mathbf{c}$ axis emphasizing trigonal $\left[\mathrm{SbS}_{3}\right]$ pyramids. Classical anisotropic refinement, ellipsoids are drawn at the $50 \%$ probability level.

The $\mathrm{Ag}$ atoms are located between the $\mathrm{SbS}_{3}$ pyramids and link these coordination units together via short S-Ag-S bonds (2.444 $\AA$ and $2.448 \AA$ ). These short $\mathrm{S}-\mathrm{Ag}$ bonds form two spiralling systems (left- and righthanded) running parallel to the $\mathbf{c}$ axis (Fig. $3 \mathrm{a}-\mathrm{b}$ ). In addition, each $\mathrm{Ag}$ atom is also surrounded by two $\mathrm{S}$ atoms at distances of $2.875 \AA$ and $3.163 \AA$. This $2+1+1$ coordination scheme of $\mathrm{Ag}$ atom resembles the coordination of $\mathrm{Ag} 2$ atom found in the structure of stephanite, $\mathrm{Ag}_{5} \mathrm{SbS}_{4}$, showing $\mathrm{Ag}-\mathrm{S}$ bond distances of $2.483 \AA$, $2.596 \AA, 2.751 \AA$ and $3.030 \AA$ (Leitl et al. 2009). The closest $\mathrm{Ag}-\mathrm{Ag}$ contacts in the pyrargyrite structure are $3.250 \AA$ within the spirals and $3.548 \AA$ between them. In an alternative view, the $\mathrm{Ag}$ atoms form three nonintersect- ing chains running through the structure with the $\mathrm{Ag}-\mathrm{Ag}$ distances of $3.548 \AA$ (Fig. 3a).

The displacement parameters of $\mathrm{Ag}$ were refined in the third-order non-harmonic approximation using the Gram-Charlier expansion. A conventional refinement using anisotropic displacement parameters for all atoms led to the strongly anisotropic ellipsoids for Ag, whereas displacement ellipsoids for $\mathrm{Sb}$ and $\mathrm{S}$ atoms were almost isotropic. The results of both refinement strategies are compared in Fig. 4. The application of non-harmonic parameters led to the triangular shape of the electron density centred in $\mathrm{Ag}$ position. The reduction of electron density in the direction to $\mathrm{S}$ atoms is obvious. Sulphur atoms at distances of $2.444 \AA$ and $2.448 \AA$ have the most pronounced influence on the distribution of $\mathrm{Ag}$ electron density. The effect of symmetrically equivalent $\mathrm{S}$ atoms at distances of $2.875 \AA$ and $3.163 \AA$ is weaker.

\subsection{Possible ion diffusion pathways and activation energies for $\mathrm{Ag}$ in the pyrargyrite structure}

The joint probability density function and one particle potential are quantities often used for density modelling of ionic diffusion paths. For an isolated atom, the probability density function (PDF) is the probability (averaged in space and time) of finding the atom in a volume element around its equilibrium position. The sum of all contributions of single PDFs is then called the joint probability density function (JPDF) and it is very useful (and unique) especially in ionic conductors with a continuous distribution of ions along conduction paths. The JPDF can be directly calculated from the refined parameters as

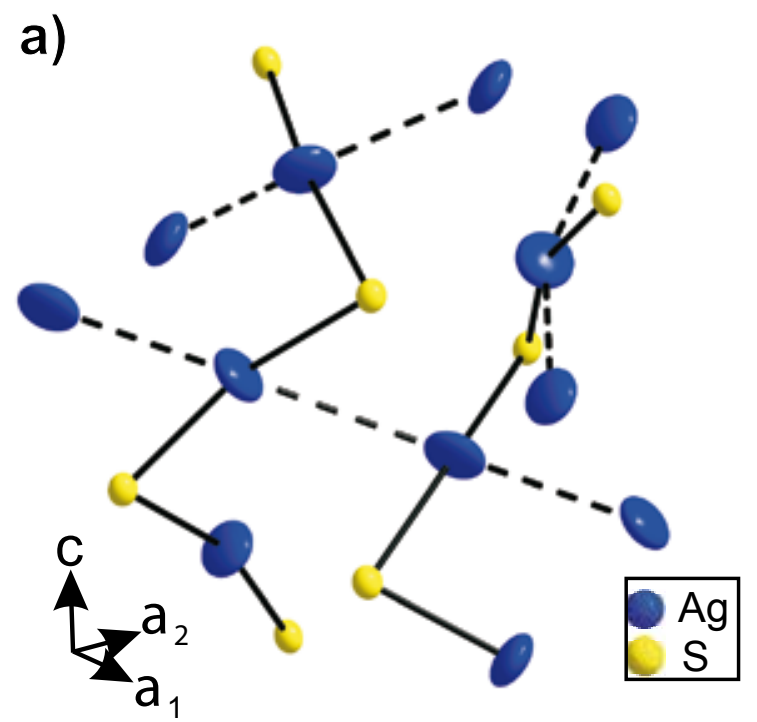

b)

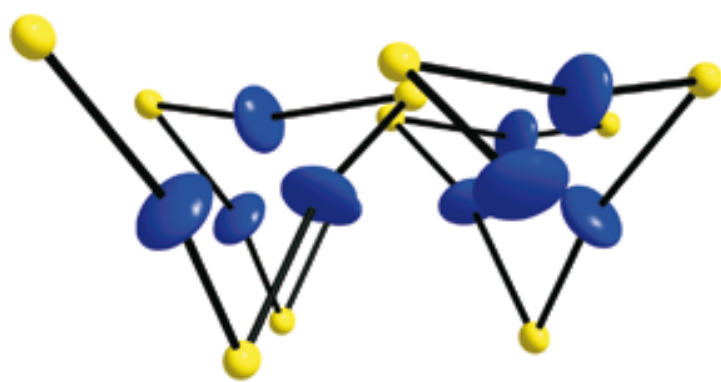

Fig 3a The spiralling system of short $\mathrm{S}-\mathrm{Ag}-\mathrm{S}$ bonds (continuous lines) and $\mathrm{Ag}-\mathrm{Ag}$ chains (dashed lines) in the crystal structure of pyrargyrite. b - Central projection of two neighbouring $\mathrm{S}-\mathrm{Ag}-\mathrm{S}$ spirals (right- and left-handed) viewed along the $\mathbf{c}$ axis. Ellipsoids are drawn at the $50 \%$ probability level. 
a)

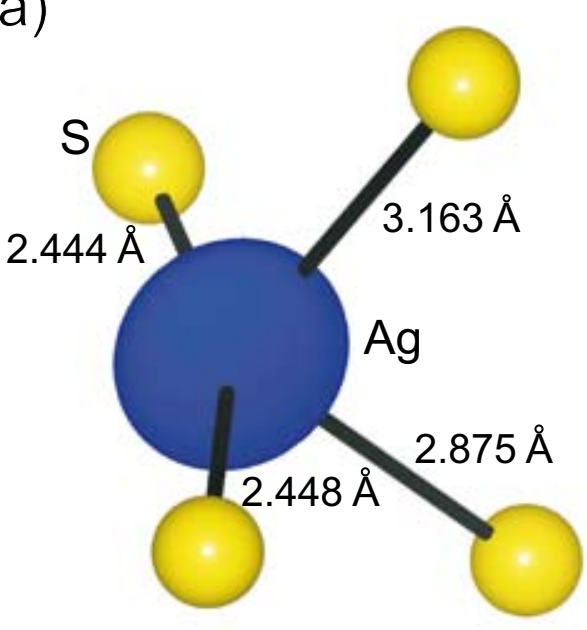

b)

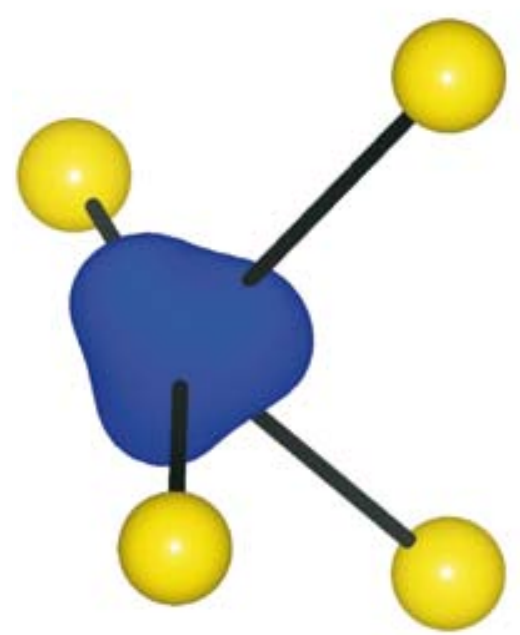

Fig. 4. Coordination of Ag site in pyrargyrite structure. Comparison showing classic anisotropic refinement (a) and non-harmonic refinement using JPDF maps (b). Four $\mathrm{S}$ atoms coordinate the $\mathrm{Ag}$ atom in $2+1+1$ coordination.
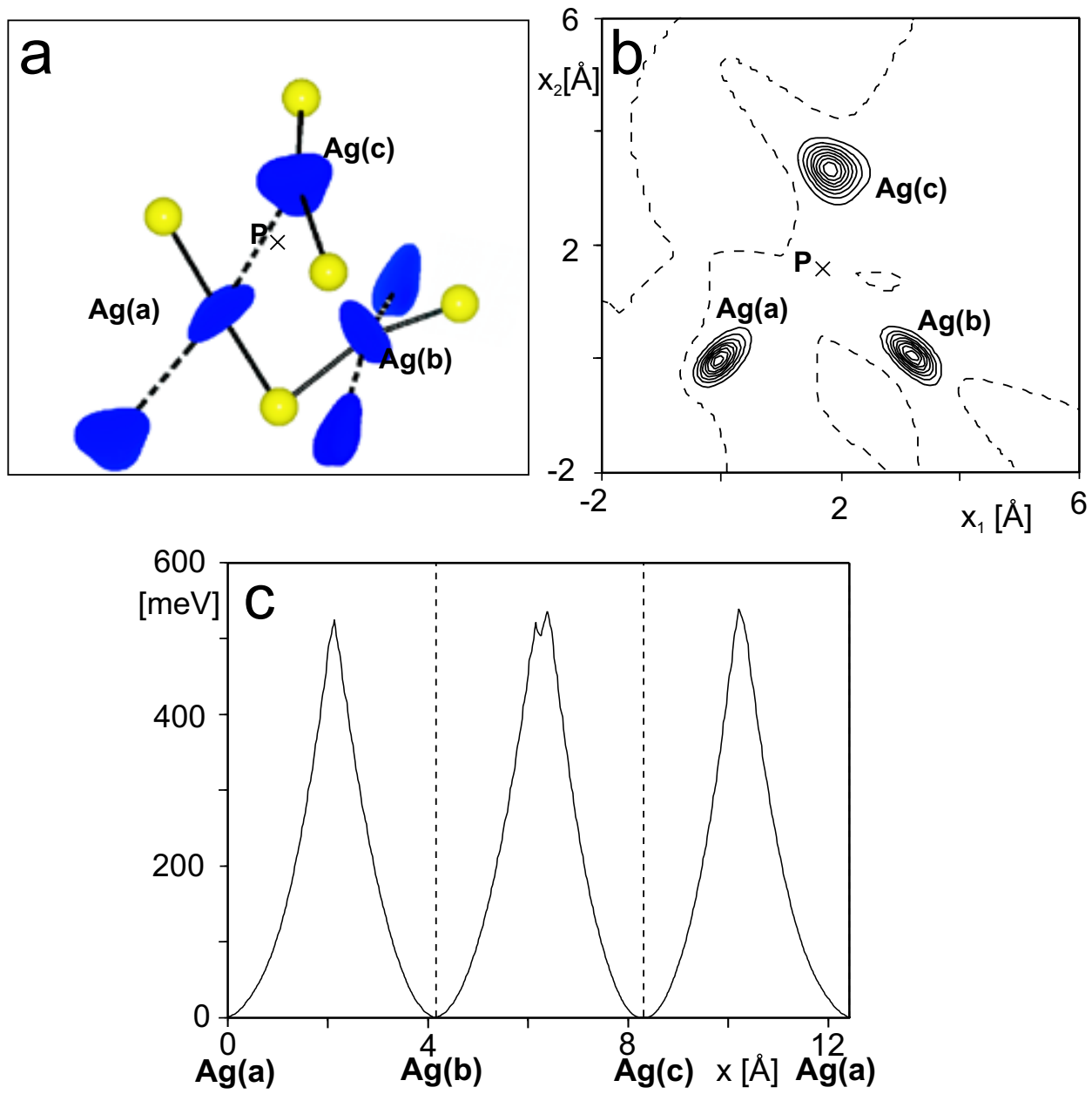

Fig. 5a Joint probability isosurface for $\mathrm{Ag}$ in the pyrargyrite structure; sulphur atoms in arbitrary size. $\mathrm{Ag}-\mathrm{S}-\mathrm{Ag}$ spirals and $\mathrm{Ag}-\mathrm{Ag}$ chains are indicated by solid and dashed lines, respectively. $\mathbf{b}$ - Section of JPDF of $\mathrm{Ag}$ atoms through the $\operatorname{Ag}(\mathrm{a}), \operatorname{Ag}(\mathrm{b}) \operatorname{and} \operatorname{Ag}(\mathrm{c})$ positions in pyrargyrite. Contour lines in intervals of $0.5 \AA^{-3}$ for positive values (continuous lines) and in intervals $0.02 \AA^{-3}$ for negative values (dashed lines). The maximum and minimum probability density values are in 4.45 and $-0.02 \AA^{-3}$, respectively. c - One-particle potential along $A g(a)-P-A g(b)-P-A g(c)-P-A g(a)$ diffusion path calculated for pyrargyrite at room temperature. 
the weighted superposition of the Fourier transform of the non-harmonic displacement factors of atoms over several sites. The One Particle Potential (OPP) is the average potential energy of an atom caused by the interaction with all the other atoms of the crystal and allows an estimation of the potential barrier for ionic motion (Bachmann and Schulz 1984).

The non-harmonic refinement of pyrargyrite structure showed approximately triangular shape of electron density centred at $\mathrm{Ag}$ atoms. Inspecting the Fig. 5a, it is evident that the electron densities of three neighbouring Ag atoms slightly smear towards the position labelled as $\mathrm{P}$. Two of these $\mathrm{Ag}$ atoms (labelled as $\mathrm{Ag}(\mathrm{a})$ and $\mathrm{Ag}(\mathrm{b})$ ) are located on the same $\mathrm{Ag}-\mathrm{S}-\mathrm{Ag}$ spiral running along the c axis, the third $\mathrm{Ag}$ atom (labelled as $\mathrm{Ag}(\mathrm{c})$ ) is situated on the neighbouring spiral. Gagor et al. (2009) reported similar behaviour during the refinement of isostructural proustite, $\mathrm{Ag}_{3} \mathrm{AsS}_{3}$.

The two-dimensional JPDF of Ag atoms constructed as a section through $\operatorname{Ag}(a), \operatorname{Ag}(b)$ and $\operatorname{Ag}(c)$ equilibrium positions is shown in Fig. 5b. Finally, the OPPs along the possible diffusion path $\mathrm{Ag}(\mathrm{a})-\mathrm{P}-\mathrm{Ag}(\mathrm{b})-\mathrm{P}-\mathrm{Ag}(\mathrm{c})-\mathrm{P}-\mathrm{Ag}(\mathrm{a})$ corresponding to the possible migration route of silver were calculated (Fig. 5c). Practically the same value of activation energy of $0.52 \mathrm{eV}$ was obtained between all Ag positions. These values of OPP suggest that the silver transfer within and between neighbouring $\mathrm{Ag}-\mathrm{S}-\mathrm{Ag}$ spirals is equally probable. Taking into account the Ag chains existing in the pyrargyrite structure, the migration of silver within and between these chains is also possible with the same probability. The silver transfer between all above described $\mathrm{Ag}$ positions may happen through the additional P site. Because of slightly negative $\left(-0.02 \AA^{-3}\right)$ probability density values found approximately in the middle of joins (see Fig. 5b) connecting two adjacent Ag sites, the direct migration of $\mathrm{Ag}$ is not possible. Interestingly, no dependence between the distances of Ag sites and values of OPP was observed. Similar results were obtained for the proustite structure by Gagor et al. (2009). Impedance spectroscopic studies of natural pyrargyrite performed by Schönau and Redfern (2002) yielded activation energy of $0.40 \mathrm{eV}$. This value is in agreement with the potential barrier reported in this study, which was calculated using the JPDF via an additional P site.

\section{Conclusions}

We found the crystal structure of pyrargyrite in principal similar to that reported by Engel and Nowacki (1966). Antimony atoms form a pyramidal $\mathrm{SbS}_{3}$ unit, which is a characteristic feature of sulphosalt structures. These pyramids are oriented in one direction, which explains the polar character of pyrargyrite and its hemimorphic morphology. The Ag atoms are located between these pyramids and connect them by relatively short $\mathrm{S}-\mathrm{Ag}-\mathrm{S}$ bonds. The application of non-harmonic Gram-Charlier development of the silver atomic displacement parameters enabled us a better description of electron density of $\mathrm{Ag}$, which is usually difficult to determine in ionic conductors. Approximately triangular shape of silver electron density was observed. The analysis of potential barriers between $\mathrm{Ag}$ sites reveals that silver transfer is equally probable via additional $P$ site not only within the $\mathrm{Ag}-\mathrm{S}-\mathrm{Ag}$ spirals and $\mathrm{Ag}-\mathrm{Ag}$ chains, but also between these spirals and chains.

Acknowledgements. This work was supported by internal project of Czech Geological Survey (323000) to FL, project MK00002327201 to JS and the institutional research plan No. AVOZ10100521 of the Institute of Physics to MD. The authors are grateful to Vašek Petrríček (Institute of Physics, Prague, AS ČR) for valuable comments on the non-harmonic refinement and to Pavel Škácha (Faculty of Science, Charles University, Prague) for providing the pyrargyrite samples. Comments and suggestions by Jan Filip, Jakub Plášil and handling editor Roman Skála were greatly appreciated. Last but not least, the authors express their sincere thanks to Vojtěch Janoušek for his valuable editorial work.

\section{References}

Bachmann R, Schulz H (1984) Anharmonic potentials in ordered and disordered crystals. Acta Cryst A 40: 668-675

Bindi L, Evain M (2007) Gram-Charlier development of the atomic displacement factors into minerals structures: the case of samsonite $\mathrm{Ag}_{4} \mathrm{MnSb}_{2} \mathrm{~S}_{6}$. Amer Miner 92: 886-891

Bindi L, Evain M, Pradel A, Albert S, Ribes M, Menchetti $S$ (2006) Fast ion conduction character and ionic phasetransitions in disordered crystals: the complex case of the minerals of the pearceite-polybasite group. Phys Chem Miner 33: 677-690

Bindi L, Evain M, Spry G, Tait KT, Menchetti S (2007a) Structural role of copper in the minerals of the pearceitepolybasite group: the case of the new minerals cupropearceite and cupropolybasite. Mineral Mag 71: 641-650

Bindi L, Evain M, Menchetti S (2007b) Complex twinning, polytypism and disorder phenomena in the crystal structures of antimonpearceite and arsenpolybasite. Canad Mineral 45: 321-333

Boucher F, Evain M, Brec R (1993) Distribution and ionic diffusion path of silver in $\gamma-\mathrm{Ag}_{8} \mathrm{GeTe}_{6}$ : a temperature dependent anharmonic single crystal diffraction study. J Solid State Chem 107: 332-346 
Engel P, Nowacki W (1966) Die Verfeinerung der Kristallstruktur von Proustit, $\mathrm{Ag}_{3} \mathrm{AsS}_{3}$ und Pyrargyrit, $\mathrm{Ag}_{3} \mathrm{SbS}_{3}$. Neu Jb Mineral, Mh 1966: 181-184

Gągor A, PawŁowski A, Pietrazsko A (2009) Silver transfer in proustite $\mathrm{Ag}_{3} \mathrm{AsS}_{3}$ at high temperatures: conductivity and single-crystal X-ray studies. J Solid State Chem 182: $451-456$

Gaudin E, Brocher F, Petříčé P, Taulelle F, Evain M (2000) Structures and phase transition of the $\mathrm{A}_{6} \mathrm{PSe}_{6}$ (A $=\mathrm{Ag}, \mathrm{Cu}$ ) argyrodite-type ionic conductors. II. Beta- and gamma - $\mathrm{Cu}_{7} \mathrm{PSe}_{6}$. Acta Crystallogr B56: 402-408

Gaudin E, Boucher F, Evain M (2001) Some factors governing $\mathrm{Ag}^{+}$and $\mathrm{Cu}^{+}$low coordination in chalcogenide environments. J Solid State Chem 160: 212-221

GHosal S, SACK RO (1995) As-Sb energetics in argentian sulphosalts. Geochim Cosmochim Acta 59: 3573-3579

HARKER D (1936) The application of the three-dimensional Patterson method and the crystal structures of proustite, $\mathrm{Ag}_{3} \mathrm{AsS}_{3}$, and pyrargyrite, $\mathrm{Ag}_{3} \mathrm{SbS}_{3}$. J Chem Physics 4: 381-390

Harlov DE, SACK RO (1995) Ag-Cu exchange equilibria between pyrargyrite, high-skinnerite, and polybasite solutions. Geochim Cosmochim Acta 59: 867-874

Herrendorf W (1993) Habitus. Unpublished Ph.D. thesis, University of Karlsruhe, Germany

KuHs WF (1992) Generalized atomic displacements in crystallographic structure analysis. Acta Crystallogr A 48: 80-98

Kutoglu A (1968) Die Struktur des Pyrostilpnits (Feuerblende) $\mathrm{Ag}_{3} \mathrm{SbS}_{3}$. Neu Jb Mineral, Mh 1968: 145-1160
Leitl M, Pfitzner A, Bindi L (2009) Preferred ion diffusion pathways and activation energies for Ag in the crystal structure of stephanite, $\mathrm{Ag}_{5} \mathrm{SbS}_{4}$. Mineral Mag 73: 17-26

Oxford Diffraction (2008) CrysAlis CCD and CrysAlis RED. Oxford Diffraction Ltd, Yarnton, UK

Palatinus L, Chapuis G (2007) SUPERFLIP - a computer program for the solution of crystal structures by charge flipping in arbitrary dimensions. J Appl Cryst 40: 786-790

Petříček V, Dušek M, Palatinus L (2006) JANA2006, a crystallographic computing system. Institute of Physics, Academy of Sciences of the Czech Republic, Prague

Pouchou JL, Pichoir F (1985) "PAP” ( $\varphi \rho Z)$ procedure for improved quantitative microanalysis. In: ArMSTRONG JT (ed) Microbeam Analysis. San Francisco Press, San Francisco, pp 104-106

SCHÖNAu KA, REDFERn SAT (2002) High-temperature phase transitions, dialectric relaxation, and ionic mobility of proustite, $\mathrm{Ag}_{3} \mathrm{AsS}_{3}$, and pyrargyrite, $\mathrm{Ag}_{3} \mathrm{SbS}_{3}$. J Appl Phys 92: 7415-7424

Sejkora J, Litochleb J, KnížeK F, ŠKÁcha P (2007) The characteristic of occurrence Ag-mineralization at the H61Z vein below $6^{\text {th }}$ level of the mine 21 - Háje, the Prríbram uranium-polymetallic ore district (Czech Republic). Bull mineral-petrolog Odd Nár Muz (Praha) 14-15: 107-113 (in Czech)

Strunz H, Nickel EH (2002) Strunz Mineralogical Tables. E. Schweizerbart'sche Verlagsbuchandlung (Nägele u. Obermiller), Stuttgart, pp 1-870 